\title{
PEGARUH MEDIA TERHADAP PERTUMBUHAN BIBIT JAMBU METE (Anacardium occidental. L)
}

\author{
R. Azimi Wahid, Kemas Usman \\ aProgram Studi Kehutanan Universitas Pendidikan Mandalika, Jl. Pemuda No. 59A Dasan Agung, Mataram \\ *corresponding author: Azimiwahid1922@gmail.com
}

\begin{abstract}
Abstrak
Tujuan penelitian ini adalah Untuk Mengetahui Pengaruh Media Pembibitan Terhadap Pertumubuhan Bibit Jambu Mete (Anacardium occidentale L.). Metode yang digunakan dalam penelitaian ini adalah metode eksperimen, tehnik pengumpulan data dilakukan dengan metode Rancangan Acak Lenkap (RAL). Penelitian ini dilakukan di Green house Peneliti di Sambleia, Kecamatan Sambelia Kabupaten Lombok Timur. Hasil penelitian ini menunjukan pada pertumbuhan jambu mete pada perlakuan P3 (campuran tanah dan sekam) memberikan pola pertambahan tinggi batang pada minggu kedua sampai kedelapan tidak berbeda signifikan dan pada pertambahan jumlah daun pada minnggu 1,2,3,5,7,8 tidak berbeda signifikan.
\end{abstract}

Kata Kunci: Media, Pertumbuhan, Jambu Mete

How to Cite: Wahid, R. A. dan Usman, K. (2021) 'Pegaruh Media Terhadap Pertumbuhan Bibit Jambu Mete (Anacardium occidental. L)', Jurnal Silva Samalas: Journal of Forestry and Plant Science, 4 (1), pp. 33-38.

\section{PENDAHULUAN}

Bibit yang berkualitas baik umumnya mampu bertahan terhadap keadaan lingkungan yang kurang baik, karena itu untuk mendapatkan pertumbuhan bibit yang kuat dan sehat, perlu dilakukan upaya perbaikan dalam tehnik budidaya dalam pembibitan (Mardjono dalam Dwiwarni, 1990). Bibit bermutu baik didapat apabila selama kurun waktu pembibitan unsur hara yang diperluka tanaman dalam pertumbuhannya terpenuhi dan media tumbuhnya dapat menunjang perakaran tanaman (Wisardja dan Sukawidana, dalam Winten, dkk, 2015).

Lingkungan tumbuh untuk perakaran yang optimal adalah media tanam yang menyediakan kebutuhan udara, air, dan hara secara optimal. Hal tersebut dapat dipenuhi apabila kondisi struktur media tanam memiliki keseimbangan porositas udara dan air yang baik. Pertumbuhan akar dalam polybag sangat ditentukan oleh air dan nutrisi yang ada di dalamnya (Erwiyono 2005).

Pembibitan adalah langkah awal untuk pertanaman berikutnya, oleh karena itu pembibitan harus memperoleh perlakuan tertentu agar kelak diperoleh bibit yang siap tanam (Hariwangsa, 2013). Media yang digunakan untuk pembibitan harus mempunyai sifat fisik dan kimia yang baik. media pembitan biasanya berupa campuran tanah dan bahan organik dengan perbandinga tertentu (Maulana, 2016). Nurhayati dkk, dalam Winten (2015) menyatakan bahwa bahan organik akan sangat mempengaruhi sifat dan ciri-ciri tanah, pengaruh bahan organik pada ciri fisik tanah seperti kemampuan menahan air meningkat, warna tanah menjadi coklat hingga hitam, merangsang granulasi agregat dan memantapkannya, menurunkan plastisitas, kohesi dan sifat buruk lainnya dari liat.

Hasil analisis tanah penelitian menunjukkan, bahwa kandungan $\mathrm{N}$ dalam tanah rendah dan $\mathrm{C}$ organiknya sedang. Tingkat keasaman tanah $(\mathrm{pH})$ tanah yang optimal yaitu sekitar 6-7 dan masih bisa tumbuh pada $\mathrm{pH}$ 5. Tanaman jambu mete rakus terhadap unsur hara terutama $\mathrm{N}, \mathrm{P}, \mathrm{K}$ (indra winten, dkk 2015). Oleh karena itu penelitian tentang Pengaruh Media Terhadap Pertumbuhan bibit Jambu 
Mete (Anacarduim occidentale.L) yang sesuai dengan persyaratan tumbuh tanaman jambu mete agar jambu mete yang dihasilkan berproduktivitas tinggi. Penelitian ini bertujuan untuk mengetahui pegaruh media terhadap pertumbuhan bibit jambu mete (Anacarduim occidental L).

\section{METODE PELAKSANAAN}

Penelitian ini merupakan penelitian eksperimental dengan menerapkan beberapa variabel didalamnya. Variabel bebas adalah media pertumbuhan bibit jambu mete. Variabel terikat adalah tinggi bibit jambu mete. Variabel kontrol digunakan untuk homogenisasi faktor lingkungan diantaranya: penyiraman, perawatan bibit, intensitas cahaya matahari. Penelitian dilakukan di pembibitan jambu mete di Desa Sambelia.

\section{a. Alat dan Bahan}

Alat yang digunakan dalam penelitian ini adalah : alat tulis, alat ukur tanaman (kaliper dan mistar), pita label,sarung tangan, hekter, kamera, cutter,gunting, baskom, sprayer, dan kamera. Bahan yang digunaka dalam penelitian ini adalah : Bibit jambu mete, Tanah, Sekam, kompos, Polybag

\section{b. Rancangan Percobaan}

Penelitian ini menggunakan Rancangan Acak Lengkap (RAL) yang terdiri dari 4 perlakuan dan 3 ulangan. Setiap ulangan terdiri atas 3 tanaman,sehingga terdapat 12 satuan percobaan pembibitan biji jambu mete. Perlakuan media yang di uji adalah : tanah (P1), kombinasi tanah-kompos (P2), kombinasi tanah- sekam (P3) dan kombinasi kompos tanah dan sekam (P4). Perbandingan media tanam berdasarkan volume untuk setiap perlakuan sebagai berikut :

Tabel 1 Tata Letak Percobaan RAL

\begin{tabular}{lll}
\hline P1 & P3 & P1 \\
\hline P4 & P2 & P3 \\
\hline P2 & P2 & P4 \\
\hline P3 & P1 & P2 \\
\hline
\end{tabular}

Keterangan :

$\mathrm{P} 1=$ media tanah $($ kontrol $)$

$\mathrm{P} 2=$ media tanah - kompos $=(50: 50) \%$

$\mathrm{P} 3=$ media tanah - sekam $=(50: 50) \%$

$\mathrm{P} 4=$ media tanah- sekam - kompos $=(40 \%: 30 \%: 30 \%)$

\section{c. Cara Kerja}

Benih jambu mete disemai terlebih dahulu di dalam bak semai. Persiapan pembuatan media tanam berupa polybag ukuran $5 \mathrm{~cm} \times 10 \mathrm{~cm}$ media tanah, kemudian pupuk organik. Pupuk organik yang digunakan yaitu pupuk kompos. Pencampuran media tanah dengan pupuk organik dilakukan sesuai dengan perlakuan yaitu tanah (P1), kompos (P2), sekam (P3),kombinasi tanah-kompos (P4), kombinasi tanah-sekam (P5) dan kombinasi tanah-kompos-sekam (P6). Pemindahan bibit jambu mete dilakukan pada sore hari dengan tujuan agar daun pada bibit tidak layu.

\section{Persiapan Areal}

Areal yang digunakan dalam penelitian ini adalah yang memiliki pencahayaan yang optimal, jauh dari gangguan hama dan penyakit, dekat dengan sumber air dan mudah untuk di awasi. Areal kemudian dibersihkan dan tanahnya diratakan agar memudahkan dalam penempatan polybag.

2. Penyiapan Semai Semai yang digunakan adalah semai langsung dari bibit jambu mete yang di semai di trai pembibitan berumur \pm 1 minggu. semai dipindahkan ke dalam polibag sesuai dengan medianya

3. Penyiapan Media Tanam

Sebelum dicampur tanah, kompos dan sekam dikering anginkan. Masing-masing media di ambil sesuai volume perlakuan dan media kombinasi di campur sesuai perlakuan hingga homogen 
kemudian dimasukkan ke dalam polybag. Setiap polybag di beri nomor/diberi kode yang berbeda sesuai dengan perlakuan media dan ulangannya.

4. Penanaman

Trai persemaian yang siap untuk di pindahkan kemudian semai tersebut di pindahkan dengan hatihati ditanam dalam polybag yang telah disiapkan. Polybag-polybag yang telah di tanami di siram kemudian di sungkup di green house, semai siap dipindahkan ke areal penelitian sesuai dengan rancangan penelitian yang ada.

5. Penyiraman

Penyiraman tanaman dilakukan setiap hari pada waktu pagi dan sore hari atau sesuai dengan kondisi lapangan, dan apabila dalam hari tersebut terdapat hujan maka tidak akan ada penyiraman sesuai jadwal yang ditetapkan. Disiram dengan menggunakan air sumur, volume air yang ditambahkan kesetiap tanaman tidak sama tergantung kondisi media media tanam pada saat penyiraman.

\section{d. Analsis Data}

Pengamatan dilakukan setiap seminggu sekali, selama 2 bulan. Pengambilan data dilakukan sebanyak 8 kali. Adapun variabel yang diamati dalam penelitian ini adalah sebagai berikut :

\section{Tinggi Tanaman $(\mathbf{c m})$}

Pengukuran awal tinggi tanaman dilakukan setelah proses adaptasi tanaman dilapangan selama 1 minggu. Tinggi tanaman diukur $1 \mathrm{~cm}$ (sudah ditandai dengan penanda) dari permukaan tanah sampai ke ujung titik pertumbuhan batang, di ukur dengan menggunakan penggaris.

\section{Jumlah Daun (helai)}

Jumlah daun yang dihitung adalah pertambahan jumlah daun yang muncul pada setiap pengamatan. Jumlah daun dihitung apabila tangkai daun sudah terlihat jelas walaupun anak daunnya belum terbuka secara sempurna.

\section{Panjang akar}

Panjang akar yang dihitung adalah pangkal batang sampai ujung akar menggunkan pengaris pada minggu ahir

Data ketiga parameter tersebut di analisis dengan uji ANOVA dengan taraf $\alpha=0,05$. Jika terdapat signifikansi pada perlakuan dilanjutkan dengan Uji Beda Nyata Jujur pada taraf 0,05. Uji ANOVA dan BNJ dianalisis dengan menggunakan Software excel

\section{HASIL DAN PEMBAHASAN}

Tinggi batang, panjang akar, dan jumlah daun merupakan parameter yang umum dijadikan dasar penilaian pertumbuhan bibit. Untuk penelitian bidang kehutanan biasanya memang menggunakan bibit untuk menguji suatu perlakuan (Wangiyana dan Wanitaningsih, 2018). Asumsi yang digunakan adalah jika bibit mampu tumbuh dengan baik, maka tanaman dewasa kemungkinan dapat tumbuh dengna baik pula. Jika menggunakan tanaman dewasa sebagai objek penelitian, maka waktu yang diperlukan dalam melakukan pengamatan akan relatif lama dan tidak efisien.

Tanah dan pasir merupakan dua komponen utama yang umum digunakan dalam pembibitan tanaman kehutanan. Perbandingan komposisi kedua bahan ini dalam pembibitan bibit tanaman hutan banyak dilakukan dalam berbagai riset tentang pengembangan bibit tanaman hutan (Wangiyana et al., 2020; Wangiyana, 2016). Penelitian ini menggunakan modifikasi tambahan bahan dalam medium yaitu sekam dan kompos. Tambahan kedua bahan tersebut dalam media pertumbuhan diharapkan mampu memberikan tambahan nutrisi bagi bibit tanaman, dalam hal ini bibit tanaman jambu mete.

Terdapat variasi berdasarkan hasil pengamatan pada parameter tinggi tanaman (Gambar 1). Minggu ke 0-4 bahwa P3 (tanah,sekam) dengan perbandingan 50\%-50\% lebih tinggi dibandingkan dengan perlakuan lainnya sedangkan pada minggu 5-8 tinggi batang yang lebih dominan yaitu dengan perlakuan P4 (tanah,sekam,kompos) dengan perbandingan 40\%-30\%-30\%. Secara umum, dapat dikatakan bahwa laju pertambahan tinggi bibit pada minggu ke -0 sampai minggu ke 8 tidak menunjukkan perbedaan yang signifikan antar media pertumbuhan yang berbeda. Dalam hal ini, waktu pengamatan 8 minggu masih relatif singkat untuk melakukan pengamatan terhadap pertumbuhan bibit tanaman hutan (Wangiyana dan Malik, 2018). 


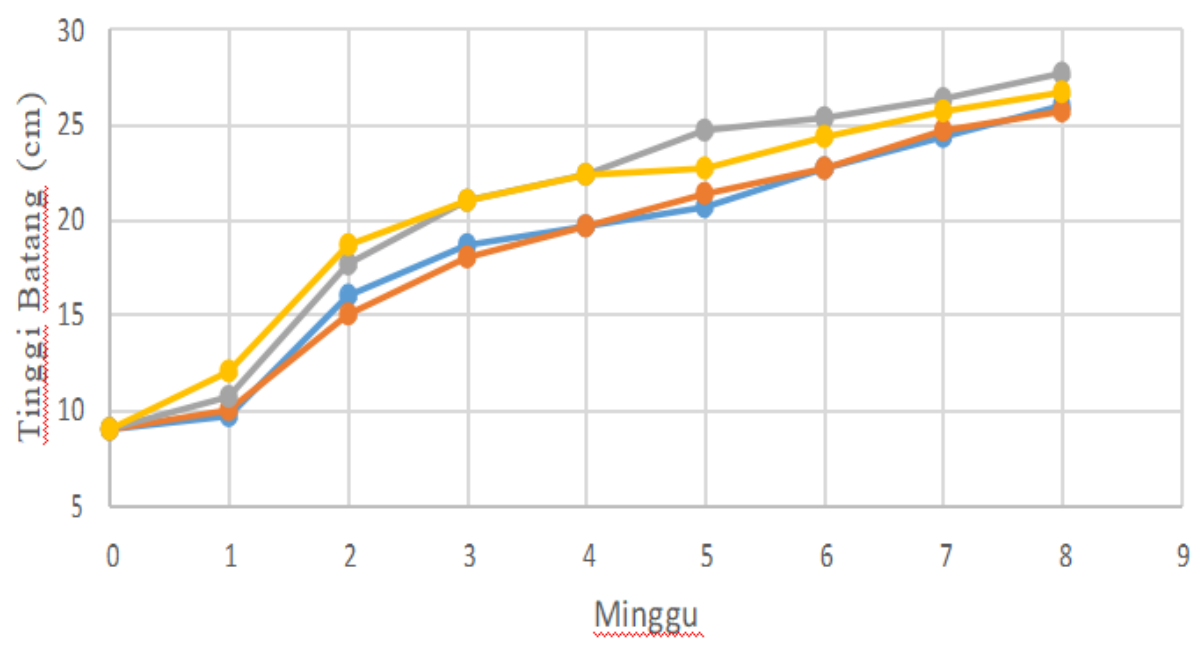

$\rightarrow-P 1 \rightarrow P 2 \rightarrow-P 3-P$ P4

Gambar 1. Grafik pertambahan tinggi batang

Jumlah daun juga dapat dijadikan parameter penting pertumbuhan bibit. Daun merupakan organ tanaman yang berperan dalam proses fotosintesis. Semakin banyak jumlah daun, maka proses fotosintesis dapat berlangsung dengan lebih efisien. Berdasarkan hasil pengamatan terhadap parameter jumlah daun, terdapat pola pertambahan jumlah daun yang kurang lebih sama pada tiap perlakuan (Gambar 2). Meskipun demikian, perlakuan P3 yang terdiri dari tanah dan sekam sedikit lebih dominan tingkat pertumbuhan jumlah daun dibandingkan dengan perlakuan lainnya. Karena merupakan parameter penting dalam pertumbuhan tanaman, jumlah daun perlu lebih ditingkatkan lagi. Salah satunya adalah dengan mengaplikasikan fitohormon yang mampu meningkatkan ukuran daun dan jumlahnya (Wangiyana dan Putri, 2019; Wangiyana et al., 2018)

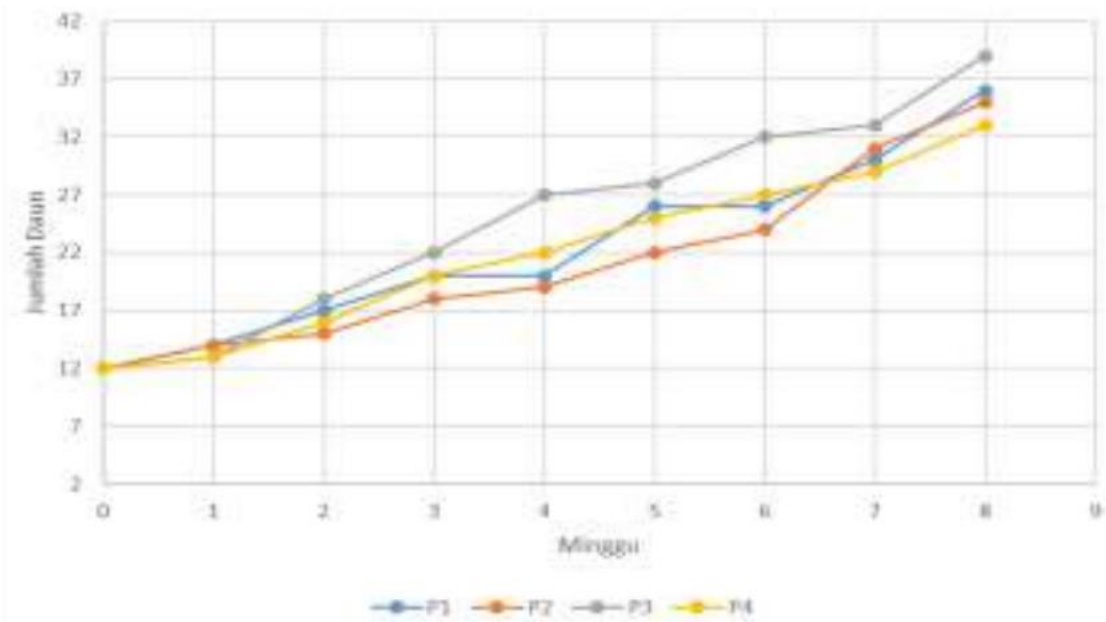

Gambar 2. Grafik jumlah daun

Panjang akar merupakan parameter terakhir pertumbuhan bibit yang diamati. Hal ini disebabkan karena untuk mengukur panjang akar, bibit jambu mete perlu dicabut dari media pertumbuhan. Oleh karena itulah pengamatan panjang akar ini hanya dilakukan sekali pada akhir waktu pengamatan (minggu ke 8). Pengamtan terhadap panjang akar menunjukkan bahwa perlakuan P4 yang merupakan media pertumbuhan paling komplit (terdiri dari tanah, sekam dan kompos) sedikit lebih dominan dalam memacu pertumbuhan panjang akar. Panjang akar pada media ini merupakan yang tertinggi dibandingkan media lainnya yaitu sebesar 12. Panjang akar terpendek dimiliki oleh bibit yang tumbuh pada media $\mathrm{P} 1$, yaitu sebesar $7 \mathrm{~cm}$. 


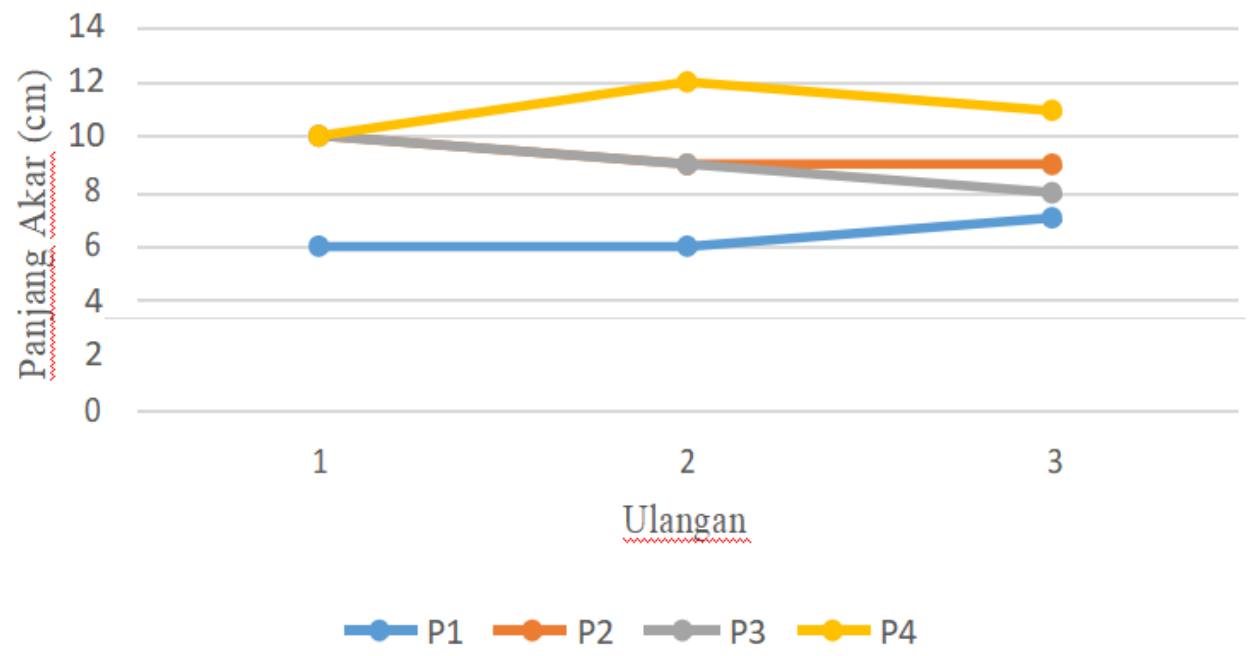

Gambar 3. Grafik tinggi akar pada akhir minggu ke-8

Secara umum, dapat dikatakan bahwa jenis media pertumbuhan berbeda tidak secara signifikan mempengaruhi pertumbuhan bibit jambu mete. Akan tetapi pada fase tertentu dari pertumbuhan tersebut, memang ditemukan perbedaan parameter pertumbuhan yang signifikan. Kemungkinan besar hasil lebih signifikan baru dapat diperoleh jika waktu pengamatan ditambah.

\section{KESIMPULAN}

Medium P3 (campuran tanah dan sekam) memberikan pola pertambahan tinggi batang dan Jumlah daun lebih baik dibandingkan medium lainnya meskipun pada beberapa minggu pengamatan pertumbuhan batang dan jumlah daun pada medium P3 (campuran tanah dan arang sekam) tidak berbeda signifikan darni medium lainnya. Sementara itu medium P4 (campuran tanah kompos dan sekam) mendukung pertumbuhan panjang akar lebih baik dibandingkan dengna medium lainnya. Meskipun tanpa adanya kandungan pupuk kompos, medium P3 mampu mendukung pertumbuhan optimal bibit dibandingkan dengan medium P4 yang mengandung kompos, hal ini mengindikasikan bahwa pada tahap awal pertumbuhannya, Jambu mete belum melakukan penyerapan nutrisi seacra optimal sehingga peran kompos belum terlalu dibutuhkan.

\section{SARAN}

Penelitian ini perlu disempurnakan untuk meningkatkan pertumbuhan baik dalam segi perlakuan maupun bibit, oleh karena itu sehingga perlu adanya penelitian lanjutan untuk melakukan penelitian ini khususnya tentang jambu mete.

\section{DAFTAR PUSTAKA}

Arif N. 2011. Pembibitan Tanaman Pala Secara Generatif. Http://Cybex.Deptan.Go.Id/Lokalita/Pem bibitan-Tanaman-Pala-Secarageneratif. [9 Maret 2014]

Chalid. (2013) 'Kajian Strategi Pengembangan Usaha Persemaian Jabon Pada Cv Karya Barokah Bogor, Jawa Barat' (Skripsi) Program Sarjana Alih Jenis Manajemen Departemen Manajemen Fakultas Ekonomi Dan Manajemen Institut Pertanian Bogor

Daras, Ekatjahjana. (2011) 'Teknologi Rehabilitasi Pada Tanaman Jambu Mete (Jurnal)", Balai Penelitian Tanaman Rempah Dan Aneka Tanaman Industri

Dwiwarni. (1990) 'Pembibitan Jambu Mete (anacardium occidentale l.) Pada Beberapa Media Dengan Menggunakan Sitosim Seed Plus (Jurnal)', Sub Balai Peneitian Bahan Rempah Natar

Erwiyono R. (2005) 'Alasan Penambahan Pupuk Kandang Dan Pasir Pada Media Tanam Di Pembibitan’ Waplusit Kopi Dan Kakao. Jember. Hal 29-35. 
Fahmi. (2015) 'Evaluasi Kesesuaian Lahan Untuk Tanaman Jambu Mete Dengan Metode Weight Factor Matching Di Kabupaten Bantul (Jurnal)' Universitas Gadjah Mada, 2015 | Diunduh Dari http://etd.repository.ugm.ac.id/

Habibi, L. (2009) 'Pembutan Pupuk Kompos Dari Limbah Rumah Tangga', Penerbit Titian Ilmu. Bandung. $74 \mathrm{Hlm}$.

Hariwangsa, I. P. (2013) 'Pengaruh Berat Benih Dan Dosis Pupuk Urea Terhadap Pertumbuhan Bibit Jambu Mete (Anacardium occidentale L)' (Skripsi). Tabanan : Universitas Tabanan.

Indra Winten, Wisardja, Suryadharma. (2015) 'Pertumbuhan Bibit Jambu Mete (Anacardium occidentale l.) Pada Berbagai Komposisi Media Tanam Dan Dosis Pupuk Urea (Jurnal)', Fakultas Pertanian Universitas Tabanan

Mangoensoekerjo S. dan H. Semangun. (2008) 'Manajemen Agribisnis Kelapa Sawit', Universitas Gajah Mada Press. Yogyakarta. 605 Hal.

Maulana. (2016) 'Pengaruh Media Pembibitan Dan Ukuran Kecambah Terhadap Pertumbuhan Bibit Pala (Myristica fragran houtt)'. (Skripsi) Departemen Agronomi Dan Hortikultura Fakultas Pertanian Institut Pertanian Bogor

Roidah, I. S. (2013) 'Manfaat Penggunaan Pupuk Organik Untuk Kesuburan Tanah". Jurnal Universitas Tulungagung Bonorowo. 1(1): 30 - 42.

Santoso, H. B. (1998) 'Pupuk Kompos'. Kanisius. Yogyakarta. $28 \mathrm{Hlm}$

Wangiyana I G. A. S. dan Wanitaningsih, S. K. (2108) 'Pkm kelompok pembibit gaharu desa kekait puncang untuk meningkatkan efisiensi produksi bibit', Lumbung Inovasi: Jurnal Pengabdian kepada Masyarakat, 3 (2), pp. 48 - 53

Wangiyana, I G. A. S. (2016) 'Phylogenetic Analysis of Aquilaria and Gyrinops Member Based on Trnl-Trnf Gene Sequence of Chloroplast', Jurnal Sangkareang Mataram, 2 (4), pp. 41 - 46

Wangiyana, I G. A. S. dan Malik, S. (2018) 'Application of Arbuscular Mycorrhiza from Senaru Forest Rhizosphere for Gyrinops versteegii Germination and Growth', Biosaintifika, 10 (2), pp. $432-438$.

Wangiyana, I G. A. S. dan Putri, D. S. (2019) 'Aplikasi Zat Pengatur Tumbuh dan Kegiatan Pruning Dalam Optimalisasi Budidaya Gaharu Di Desa Duman Kecamatan Lingsar Lombok Barat', Lumbung Inovasi: Jurnal Pengabdian kepada Masyarakat, 4 (2), pp. 36 - 42.

Wangiyana, I G. A. S., Wanitaningsih, S. K., Sanjaya, A. (2018) 'Bioinduksi Gyrinops versteegii Menggunakan Inokulan Berbahan Baku Medium Tauge dengan Berbagai Kedalaman Pengeboran. In: Seminar Nasional Implementasi Iptek Pertanian Berkelanjutan yang Tangguh Menuju Kedaulatan Pangan. Mataram, Universitas Mataram, 27 Januari 2018.

Wangiyana, I. G. A. S., Wanitaningsih, S. K., Anggadhania, L. (2020) 'Pelatihan teknologi bioinduksi untuk petani gaharu di Desa Pejaring, Kabupaten Lombok Timur', Agrokreatif: Jurnal Ilmiah Pengabdian Kepada Masyarakat, 6(1), pp. 36-44.

Wasfandriyanto, A. E. (2016) 'Respons Bibit Setek Lada (Piper nigrum L.) pada Berbagai Media Tanam Dan Konsentrasi ZPT'. Skripsi. Sekolah Tinggi Ilmu Pertanian Dharma Wacana Metro. Lampung. $77 \mathrm{Hlm}$. 